\title{
Connection of Social Policy Implementation with the Dynamics of Social Orphanhood in Russian Regions
}

\section{Conexión de la implementación de la política social con la dinámica de la orfandad social en las regiones rusas}

\author{
Evgeniya M. Bronnikova* \\ Russian State Social University, Moscow, Russian Federation \\ ORCID: https://orcid.org/0000-0002-5409-9726 \\ Olga S. Kulyamina \\ Russian State Social University, Moscow, Russian Federation \\ ORCID: https://orcid.org/0000-0001-7715-5551 \\ Sergey V. Babakaev \\ Russian State Social University, Moscow, Russian Federation \\ ORCID: https://orcid.org/0000-0001-9332-9347 \\ Marina V. Vinogradova \\ Russian State Social University, Moscow, Russian Federation \\ ORCID: https://orcid.org/0000-0002-5051-9404
}

Anna A. Larionova

The Kosygin State University of Russia, (Technology. Design. Art), Moscow, Russian Federation

ORCID: https://orcid.org/0000-0002-7797-9566

Received 02-12-20 Revised 02-25-20 Accepted 06-13-20 On line 06-29-20

*Correspondence

Email: BronnikovaEM@rgsu.net
Cite as:

\footnotetext{
Bronnikova, E.M., Kulyamina, O.S., Babakaev, S.V., Vinogradova, M.V., Larionova, A.A. (2020). Connection of Social Policy Implementation with the Dynamics of Social Orphanhood in Russian Regions. Propósitos y Representaciones, 8 (SPE2), e644. Doi: http://dx.doi.org/10.20511/pyr2020.v8nSPE2.644
} 


\section{Summary}

The problem of social orphanhood is one of the most important fmong the social problems of modern Russia, it is acute for a society. In the study of the problems of social orphanage, we used the author's methods of ranking the regions of Russia according to the dynamics of indicators, an integrated index of "favorable" changes, as well as rating data and indicators of the development of regions of Russia implemented by subjects of social policy and the system of protecting children's rights. Based on the results of the study, the main problems in the social protection of families and citizens in difficult situations are identified. The problems lie in the areas of financial security of social programs, legislative regulation, information support. The results of the study can be used in the activities of social support services. The preventive of social orphanage should be measures of an active social policy.

Keywords: Social Orphanhood; Social Policy;Socio-Economic Situation; State Programs of Social Support; Index of Favorable Changes; Index of Effectiveness of Social Support.

\section{Resumen}

El problema de la orfandad social es uno de los más importantes entre los problemas sociales de la Rusia moderna, es grave para una sociedad. En el estudio de los problemas del orfanato social, utilizamos los métodos del autor para clasificar las regiones de Rusia de acuerdo con la dinámica de los indicadores, un índice integrado de cambios "favorables", así como datos de calificación e indicadores del desarrollo de las regiones de Rusia. Rusia implementada por temas de política social y sistema de protección infantil. Con base en los resultados del estudio, se identifican los principales problemas en la protección social de familias y ciudadanos en situaciones difíciles. Los problemas radican en las áreas de seguridad financiera de los programas sociales, regulación legislativa, apoyo a la información. Los resultados del estudio pueden usarse en actividades de apoyo social. La prevención del orfanato social debe ser la medida de una política social activa.

Palabras clave: Orfandad Social; Política Social; Situación Socioeconómica; Programas Estatales de Apoyo Social; Índice de Cambios Favorables; Índice de Efectividad del Apoyo Social.

\section{Introduction}

One of the acute social problems of our time is the problem of orphanhood. Social orphanhood is the presence in the society of children left without parental care as a result of the deprivation of their parental rights, recognition of parents as incapable, missing. Not only improving the social, socio-psychological and spiritual-moral situation in society, but also the vector of social development, strengthening the traditional values of Russian society depends on solving the problem of social orphanhood. The problem of social orphanhood is an important indicator of the deformation of the social and moral foundations of society, it testifies to trouble in families, unresolved socio-economic problems, the breakdown of social ties and a weakened attention to solving social issues. Social orphanhood is an indicator of the trouble that manifests itself in different areas of social life, and primarily in the quality of life of the population, in relation to family, motherhood and childhood, in the level of family well-being.

Currently, there is no system for early diagnosis of social disadvantage in the regions, which directly affects the problem of aggravation of social orphanhood.

Caring for disadvantaged children is the main moral norm of every civilized society. There are many reasons due to which more and more children are left to the care of the state and the process of their social formation takes place outside the family in children's homes and boarding schools. In every country and in every society, there has always been, is and will be 
orphans and children who, for various reasons, are left without parental care. In this case, society and the state take care of these children development and education. A child who lost his parents is a special, truly tragic world. The need to have a family, a father and mother - one of the strongest needs of the child (Mukhina, 2001). Children abandoned by their biological parent's experience trauma affecting their future life (Perry, 2001, 2002). Any society is characterized by the following pattern: the loss or reduction of human and spiritual values in the family leads to the manifestation of child abandonment. As a consequence, growth in the number of children without parental care is witnessed. This trend is especially observed in times of economic crises and wars, as well as in the periods of transition from the old state of the social system to a new one (Korchagina, Pishnyak \& Malkova, 2010). No secret Russia today is in exactly that situation, so the relevance of this problem is obvious. In the face of social, economic and political instability of Russia the number of children in especially difficult circumstances is growing. Among them orphans, socially maladjusted children and young offenders, children with disabilities, refugees and internally displaced children living in adverse environmental conditions. The number of children orphaned at an early age is steadily increasing (Osipova, 2008). In everyday speech and theoretical studies in Russia two concepts are widely used: orphan (orphanage) and social orphan (social orphanhood). Orphaned children - children under 18 years old whose both or one of the parents died. Social orphan - a child who has biological parents, but for some reason they do not engage in raising a child and do not care about him. In this case, the society and the state take care of them (Galaguzova, 2000, p.192). These are children whose parents are not legally deprived of their parental rights, but do not actually care about their children (Vasilkova \& Vasilkova, 1999, p.299). Social orphanage is a social phenomenon, caused by the presence in a society of children without parental care due to parental rights deprivation, recognition of parent's incapable, missing.

The relevance of the topic is determined by the complexity of identifying social priorities for solving this problem and finding optimal ways to overcome social orphanhood as a massive and sustainable social phenomenon. This is primarily due to ideas about the impact of many factors of the economic, social, national-cultural, confessional, administrative and administrative order. The combination of these factors determines the general state of the problem. The problem of social orphanage is under the patronage of various departments related to health care, education, and social protection of the population. To solve the problem, a unified policy and coordination of the common actions of ministries and departments is necessary.

Most studies consider the situation with orphanhood in terms of the severity of the problem and the extent of its manifestation. The scale and severity of the problem of social orphanhood continues to grow and intensify due to the unresolved many social issues and the shortcomings of the ongoing social policy at the regional level.

\section{Methods}

Problems of social orphanage are considered by Russian authors (Volkova \& Besschetnova, 2013; Manerova \& Markina, 2019; Samokhvalova, 2016; Sgonnik, 2018). Features of changes in the family as a social institution are discussed in the works of S.P. Maribel and D.S. Roger (2018).

Foreign authors (Goldberg et al., 2020; Roche, 2019; Mihalec-Adkins, Christ \& Day, 2020; Miranda, Tadros \& Molla, 2020; Cooley et al., 2020) study the problems of orphanhood and social orphanhood, the problems of placement in foster families.

Questions of social support are discussed in the works (Kravchenko, Voitovska \& Koliada, 2020; Vasilieva \& Frolova, 2019; Kataeva \& Fomicheva, 2017). E.A. Petrova and V.G. Panushkin (2019) presented data on the dynamics of the psychological climate of Russia, which is considered as an element of assessing the favorable regions of the Russian Federation. The study was conducted in 2 main areas: 
- the analysis of the connection of the socio-economic situation of the region and the dynamics of the situation with social orphanhood;

- the role of social policy implemented in the regions as a key factor in solving the problems of social orphanhood.

The research concept is based on the classification and ranking of regions according to the changes in the development of the situation with orphans from the point of view of favorable development. Assessment of systemic changes was carried out according to a set of dynamics indicators: identification of children without parental care; placement identified social orphans in the family; annulment of decisions on the transfer of a child to a family. As a scientific tool was developed author's method of ranking and the index of "auspiciousness" changes that allow and classify the regions of the Russian Federation in four clusters: the "green" (three aspects are favorable), "yellow" (one aspect is negative, and two positive), "orange" (two aspects are unfavorable, and one is favorable), "red" (three aspects are unfavorable). The information base of indicators was made up of official documents of the Federal State Statistics Service and the Ministry of Education (form No. 103-RIC) (The forms of statistical monitoring 103-RIC, 2019; Federal State Statistics Service. Regions of Russia. Socio-economic indicators - 2018, 2019).

When conducting analysis on the socio-economic situation of the region and the dynamics of change in a situation with social orphanhood has been hypothesized the existence of a dependence between the index of "auspiciousness" and socio-economic status (Official website of the Federal state statistics service of the Russian Federation, 2019) and the development of the region, the extent of the problem of orphanhood in the region (Charity Fund "Need Help". Orphanhood in the regions of the Russian Federation, 2019), the quality of life of the population (Rating agency "RIA Rating" of the media group MIA "Russia Today", 2019). The general distribution matrices were compiled to test the hypotheses. These made it possible to conduct a comparative analysis of the selected regions for various parameters.

As part of the analysis of the role of social policy, the analysis of state social support programs was carried out, the number of programs and sets of measures at the regional level was evaluated, a qualitative assessment of the state of protection of children's rights was carried out, and an aggregated index of social support was developed. Data collected by regional Executive governmental authorities in accordance with the letter of the Ministry of education of the Russian Federation dated 24.09.2019 No.TS-2311/07 served as an information base for assessing the state of protection of children's rights.

The main goal of the study is to determine the place and role of social policy implemented in the region as a key factor in overcoming the problem of social orphanhood, and to identify areas of social development.

\section{Results}

Causes of social orphanhood are extensive, they include a decline in morals among young people, a decrease in the role of the family in raising children, the spread of alcoholism and drug addiction, the criminalization of society, lack of support and a decrease in the state's attention to the problems of motherhood and childhood.

During the analysis of the problems of social orphanhood, the dynamics of indicators of identification, placement of orphans and cancellation of decisions on transfer to the family were analyzed. The calculations made on the basis of the "auspiciousness" index of systemic shifts in the development of the general situation made it possible to distribute the Russian Federation Regions according to the level of tension of the situation. Based on the obtained distribution of Russian regions among clusters reflecting the "auspiciousness" shifts in the development of the 
situation with social orphanhood, 11 regions of the Russian Federation were selected for a more detailed study of the social situation and the ongoing social policy.

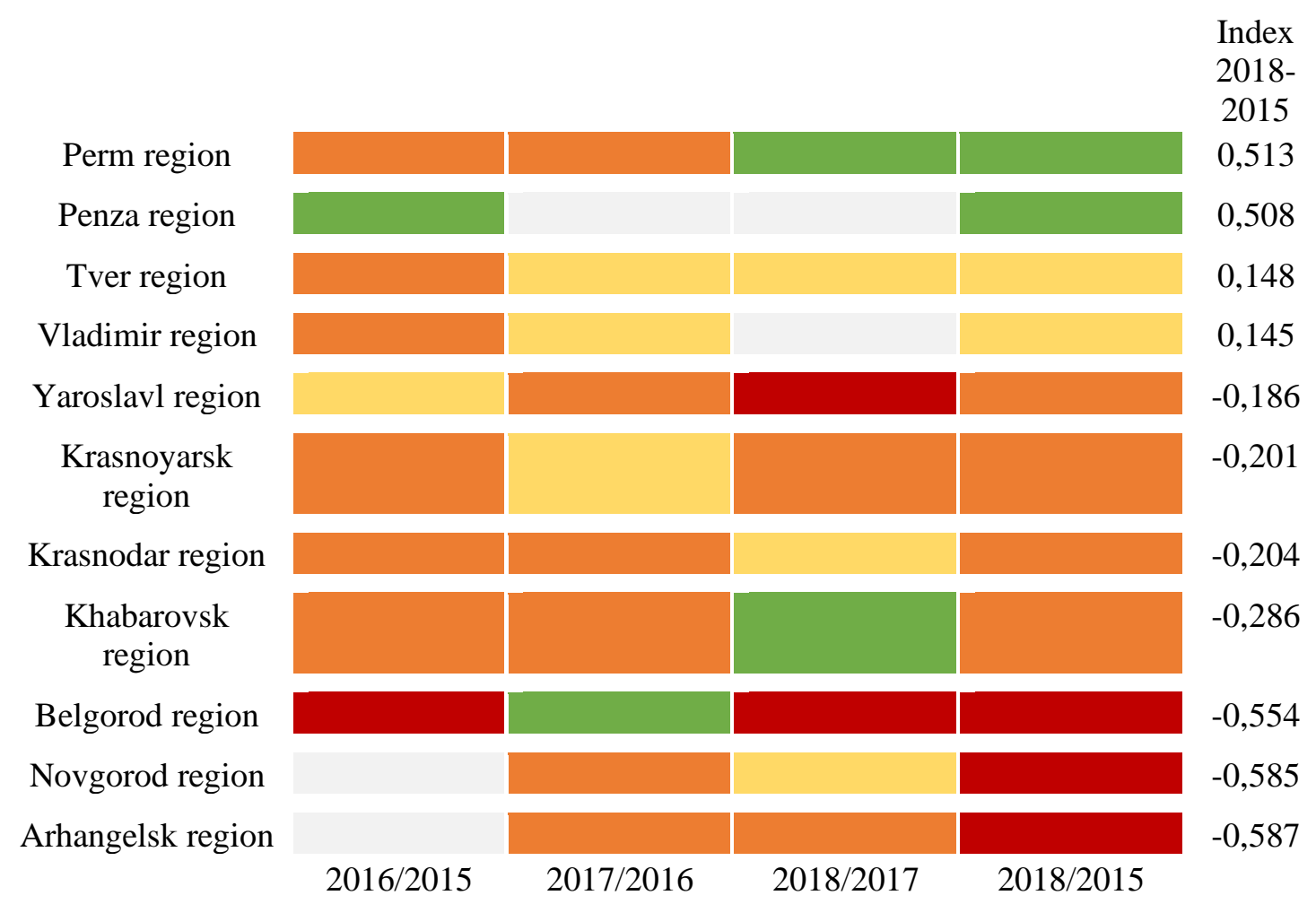

Figure 1. The dynamics of the situation of social orphanhood in selected regions of the Russian Federation

As part of the analysis of the connection between the socio-economic situation of the region and the dynamics of changes in the situation with social orphanhood, hypotheses about the dependence of various parameters on the dynamics of social orphanhood were tested.

Table 1.

The connection between the clusters of "auspiciousness" development of the situation of social orphanhood with various indicators and indexes of social development and support 


\begin{tabular}{|c|c|c|c|c|c|c|c|c|c|}
\hline 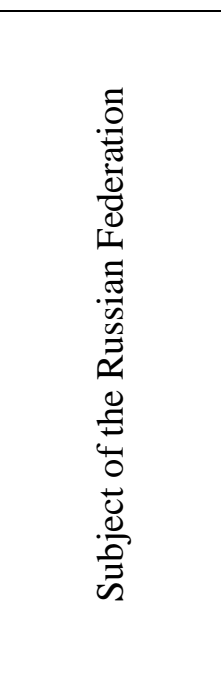 & 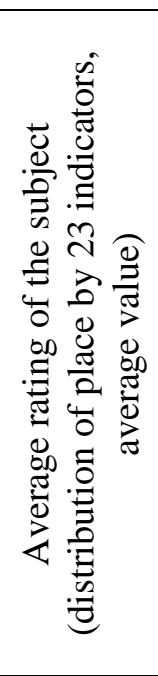 & 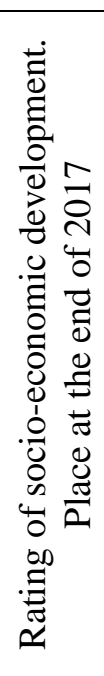 & 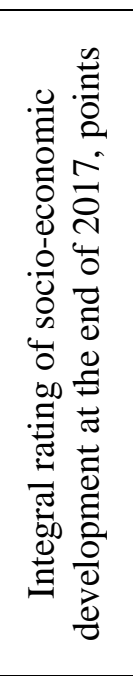 & 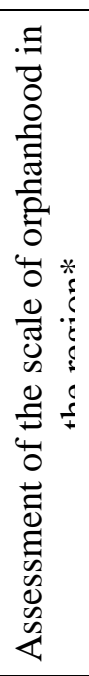 & 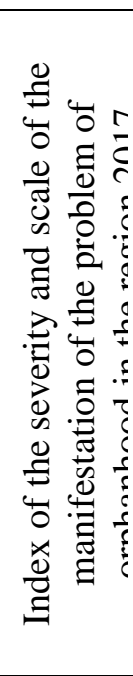 & 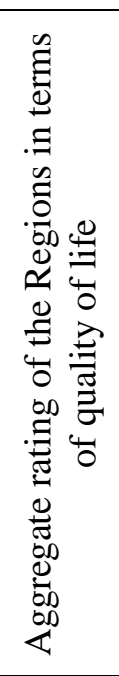 & 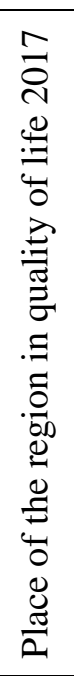 & 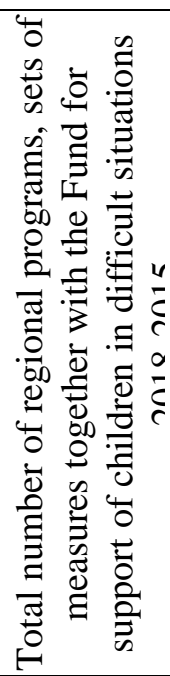 & 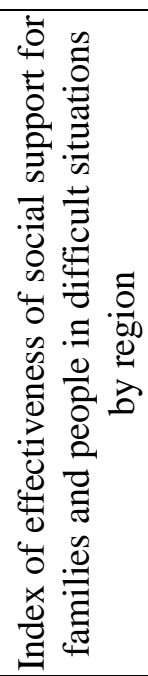 \\
\hline Perm region & 31,2 & 14 & 55.338 & B & 0,637 & 45,26 & 44 & 14 & 0,46 \\
\hline Penza region & 46,1 & 55 & 8,663 & $\mathrm{C}$ & 0,578 & 49,1 & 27 & 3 & No data \\
\hline Tver region & 46,9 & 43 & 44,17 & $\mathrm{C}$ & 0,567 & 39,46 & 64 & 17 & 0,33 \\
\hline $\begin{array}{l}\text { Vladimir } \\
\text { region }\end{array}$ & 40,9 & 48 & 41,046 & C & 0,509 & 47,34 & 32 & 23 & 0,56 \\
\hline $\begin{array}{l}\text { Yaroslavl } \\
\text { region }\end{array}$ & 42 & 46 & 42,174 & $\mathrm{C}$ & 0,444 & 49,07 & 28 & 9 & 0,41 \\
\hline $\begin{array}{l}\text { Krasnoyarsk } \\
\text { region }\end{array}$ & 23,5 & 14 & 55,338 & D & 0,352 & 46,15 & 38 & 12 & 0,5 \\
\hline $\begin{array}{l}\text { Krasnodar } \\
\text { region }\end{array}$ & 28,7 & 10 & 58,33 & A & 0,828 & 62,89 & 6 & 3 & 0,43 \\
\hline $\begin{array}{l}\text { Khabarovsk } \\
\text { region }\end{array}$ & 30,6 & 37 & 45,89 & D & 0,33 & 47,91 & 30 & 4 & 0,4 \\
\hline $\begin{array}{l}\text { Belgorod } \\
\text { region }\end{array}$ & 29,4 & 13 & 55,629 & B & 0,601 & 64 & 5 & 2 & 0,53 \\
\hline $\begin{array}{l}\text { Novgorod } \\
\text { region }\end{array}$ & 41 & 42 & 43,603 & D & 0,317 & 41,71 & 57 & 27 & 0,38 \\
\hline $\begin{array}{l}\text { Arhangelsk } \\
\text { region }\end{array}$ & 45,3 & 60 & 34,946 & B & 0,666 & 34,61 & 74 & 18 & 0,36 \\
\hline
\end{tabular}

* Orphanhood: The scale of the problem in the regions of Russia, 2017

A - low severity of the problem (prosperous regions)

$\mathrm{B}$ - the problem is expressed below average (relatively prosperous regions)

C - average severity of the problem ("average")

$\mathrm{D}$ - the problem is expressed above average (relatively problematic regions)

E - high severity of the problem (problem regions)

A continuum of orphanhood rating values is from 0 (the problem is expressed most acutely) to 1 (the most successful situation with social orphanhood).

Dependencies between the dynamics of changes in the situation with orphans and the socio-economic situation of the region have not been identified. In the "green" and "red" zones there are regions that occupy close positions in the rating, reflecting this position in terms of a comprehensive indicator. Economic growth in market conditions may run counter to social policy and the social sphere, freeing economic entities from social obligations to employees. Social obligations of the employer prevent them from achieving maximum profits and high competitiveness. Profit centers and management centers of large enterprises are removed from the regions, reducing tax revenues and payments to the regional budget. Therefore, social support programs remain underfunded, they cannot be fully implemented, they are formed according to the residual principle. In addition, economic development often exacerbates the problems of social stratification of the citizens. The income gap between 10 percent of high-income and 10 percent of low-income categories of the citizens increased to 14-15 times in the surveyed regions. 
Also, in recent years, there has been an increase in negative emotional and semantic background in the regions of Russia, caused by the lack of a goal for the development of society (Petrova \& Panushkin, 2019). This indicates the key importance of social policy and social support for the population, aimed at smoothing social contradictions and inequalities. Contradictions determine the general background of social moods, the situation of the family, and issues of motherhood and childhood. In this regard, the socio-economic development of the region is not a key factor determining the situation of social orphanhood, but only creates the conditions for the implementation of social policy and social support of the population.

According to the ratings of the socio-economic situation of the regions, no connection was found between the dynamics of changes in the situation of social orphanhood and the socioeconomic situation of the region. It is correct to conclude that the spread in the values of the indicators is non-systemic and random, which clearly indicates the absence of a connection between these variables.

The index of "auspiciousness" of changes depends slightly on the severity and scale of the problem of orphanhood in the region, which is manifested only at the most generalized level. When abstracting from specific regions and clusters and considering the dependence in the combined two groups "rather prosperous clusters ("green "and" yellow") - rather unfavorable clusters ("orange and red")", the dependence begins to be viewed. This is largely due to the use of similar and related indicators to assess these two manifestations of social orphanhood. The first aspect is the dynamics of the process. The second aspect is the severity and scale of the manifestation.

The values of the quality of life rating in regions grouped by different clusters do not allow revealing a clear and distinct connection between groups formed by aggregated parameters. Important comparison of the main criteria implemented in the area of social and information policy and aimed at improving the level and quality of life, the formation of a positive attitude towards the family, motherhood and childhood.

Separately, there is a relatively high spread of values for the total number of programs and sets of measures implemented jointly with the Fund in the regions selected for analysis. A high level of regional differentiation in addressing issues of social support is noted (Vasilieva \& Frolova, 2019). However, more programs were implemented in more successful clusters. This may indicate the importance and significance of the regional programs implemented by the Fund for the favorable development of the situation of social orphanhood in the region. Thus, cooperation with the Fund can act as a driver of positive development. The analysis of the information of children's rights protection submitted from the regions in accordance with the letter of the Ministry of Education of the Russian Federation No. TS-2311/07 dated September 24, 2019 allowed a number of conclusions to be drawn. There were no significant differences in the scope, nature, content, and effectiveness of social programs and activities aimed at social support and protection of motherhood and childhood in the regions.

Also, no fundamental differences were found in the content, relevance and extent of the prevalence of problems associated with the implementation of social programs and activities. There are some facts that indicate that social programs are implemented more effectively in the regions of the "green" and "yellow" cluster than in the regions of the "orange" and "red " cluster. However, these facts are not sustainable and systemic. At the same time, it was revealed that in the surveyed regions, comprehensive and systematic work is being carried out to implement social programs and projects with social support for childhood, motherhood, fatherhood, and families in difficult situations. Social work is aimed at reducing the scale of social orphanhood, slowing growth and solving social problems. 
The analysis of the effectiveness of social support for families and people in difficult situations was carried out. There is a strong variation in the performance index values depending on the regions was revealed. This trend may indicate a connection between the effectiveness of social support for families and people in difficult situations, on the one hand, and a decrease in the dynamics of the unfavorable development of the situation with social orphanhood on the other.

\section{Discussion}

In accordance with the identified problems and the interrelations of factors that affect the problems of social orphanhood, it is necessary to implement measures: development of the system of social protection of families, motherhood, fatherhood and childhood; increasing support for citizens in need of social assistance; simplification of procedures for providing assistance to families and citizens in difficult situations.

It is also necessary to develop the regulatory framework for the provision of social support and normative regulation of the social support sphere for motherhood and childhood. This can be done by legal elaboration of mechanisms and procedures for interaction between state, municipal, non-profit structures, as well as social entrepreneurs involved in the implementation of social projects.

The human and resource potential of social protection authorities and services that ensure the implementation of social programs should be developed to the level of modern requirements. This is possible by eliminating personnel shortages, improving the training and retraining of specialists, and increasing the level of provision of equipment and means for providing social assistance.

It is necessary to increase the level of efficiency of decision-making on the provision of social assistance and support by improving coordination of all links and authorities responsible for the implementation of social programs and activities.

An important direction is to increase the level of public awareness of rights and benefits for social support of motherhood and childhood, social advertising and public relations, and the improvement of educational and enlightenment work among the population. Educational work should be aimed at forming and strengthening family and traditional values, increasing the social significance of the problems of social orphanhood in the mass consciousness. This contributes to the strengthening of respect, protection and support for motherhood, fatherhood, and childhood in the behavior of citizens.

In the field of scientific activity, it is necessary to expand the scientific, theoretical, and methodological apparatus for studying aspects of social orphanhood, and to study the factors and conditions that affect orphanhood. These are necessary in order to develop scientific concepts, modern social technologies and innovations aimed at overcoming social orphanhood and localizing its social consequences.

It is necessary to conduct further research on the problems of social orphanhood. In particular, to identify social factors and conditions related to the causes and circumstances of the growth of neglect, the appearance of social orphans, to look for ways to increase the social responsibility of parents, to develop scientific recommendations on the localization of the problem, to determine the main activities and technologies for working with socially disadvantaged families. It is also necessary to work with foster families, to determine the main reasons, motivation and behavioral basis of citizens' decisions on the placement of orphans in their families. It is necessary to develop a system of social mechanisms for expanding the participation of citizens and families in the guardianship of orphans, to form behavioral guidelines for the adoption of children who have lost parental care. 
It is necessary to study the reasons for the refusal of foster parents from children, search for measures to reduce the cases of children return by foster parents.

The opinions and assessments of representatives of social services, state and municipal authorities responsible for the protection of motherhood, fatherhood, childhood, and child rights should be studied on issues of social orphanhood and social policy, and the public opinion of the population on issues of social orphanhood should be studied.

These directions can be realized by carrying out the In-depth interviews with citizens, abandoning adopted children, leaving their children without care, termination of parental rights, as well as other categories of citizens who are in a difficult situation. It is also possible to conduct focus groups with potential adoptive parents, expert surveys with representatives of social services. The identification of positive experience in solving problems with social orphanhood and its replication and scaling can increase the motivation of the population. These directions are able to provide positive dynamics in the development of the situation with social orphanhood in Russia.

\section{Conclusion}

The study analyzed the connection between the index of "auspiciousness" of changes in the situation of social orphanhood and the socio-economic situation and development of the region, the extent of the problem of orphanage in the region, the quality of life of the sitizens. The analysis of the connection of the socio-economic situation of the region and the dynamics of the situation with social orphanhood and the role of social policy implemented in the regions is defined.

It has been revealed that the dynamics of the situation with social orphanhood does not depend on the socio-economic situation of the region. It is largely independent of the level and pace of socio-economic development of the region. It does not depend on the quality of life in the region. It slightly depends on the scale and severity of the problem of social orphanhood in the region.

It has been revealed that the dynamics of the development of the situation with social orphans largely depends on the effectiveness of social support for families and people in difficult situations; more effective social support determines the positive dynamics of the situation with social orphanhood.

Thus, the main problems in the social protection of families and citizens in difficult situations are the problems of financial security of social programs, legislative and normative regulation, information and propaganda support, and insufficient scientific study of social policy issues, devaluation of family values, social care.

The practical significance of the work lies in the possibility of applying analysis methods and aggregated indices in analyzing the situation of social orphanhood, applying the methods and results of research in the practice of social services.

\section{References}


Charity Fund "Need Help". Orphanhood in the regions of the Russian Federation. (2019). URL: https://nuzhnapomosh.ru/research/2018/sirotstvo-v-regionakh-rf/ (accessed 09/20/2019).

Cooley, M.E., Womack, B., Rush, J., \& Slinskey, K. (2020). Adverse childhood experiences among foster parents: Prevalence and association with resilience, coping, satisfaction as a foster parent, and intent to continue fostering. Children and Youth Services Review, 109, 104699.

Federal State Statistics Service. Regions of Russia. Socio-economic indicators - 2018. (2019). URL: http://www.gks.ru/bgd/regl/b18_14p/Main.htm (accessed 09/10/2019).

Goldberg, A.E., Tornello, S., Farr, R., Smith, J.Z., \& Miranda, L. (2020). Barriers to adoption and foster care and openness to child characteristics among transgender adults. Children and Youth Services Review, 109, 104699.

Kataeva, V.I., \& Fomicheva, T.V. (2017). Socially oriented non-profit organizations (SO NPOs) for family and children in Russia: systemic problems of development. Social policy and sociology, 6(125), 45-53.

Kravchenko, O., Voitovska, A., \& Koliada, N. (2020). Social and Economic Principles of Single Mothers' Support in Ukraine. Advances in Intelligent Systems and Computing, 961, 293303

Manerova, O.A., \& Markina, A.Y. (2019). Early Social Orphanhood as a Relevant Problem of Russian Health Care (On the Example of the Chelyabinsk Region, Russia). Macedonian Journal of Medical Sciences, 7(11), 1873-1878

Maribel, S.P., \& Roger, D.S. (2018). Structural Changes in the Current Family. Reflexive Compendium. Contemporary Problems of Social Work, 4(16), 84-86.

Mihalec-Adkins, B.P., Christ, S.L., \& Day, E. (2020). An exploration of placement-related psychosocial influences on school engagement among adolescents in foster care. Children and Youth Services Review, 108, 104616.

Miranda, M., Tadros, E., \& Molla, E. (2020). The Experience of Foster Care and Long-Term Attachment. American Journal of Family Therapy, 48(1), 87-106.

Official website of the Federal state statistics service of the Russian Federation. (2019). Socioeconomic indicators-2018. URL: http://www.gks.ru/bgd/regl/b18_14p/Main.htm (accessed 15.10.2019).

Petrova, E.A., \& Panushkin, V.G. (2019). Dynamics of the psychological climate of Russia from October 2013 to June 2019. Scientific notes of the Russian State Social University, 3(152), 5-15.

Rating agency "RIA Rating" of the media group MIA "Russia Today". (2019). Rating of the quality of life of the population in the Russian regions. URL: https://riarating.com/regions/20180214/630082372.html (accessed 22.09.2019).

Roche, S. (2019). A scoping review of children's experiences of residential care settings in the global South. Children and youth services review, 105, 124-130.

Samokhvalova, A.G. (2016). Social orphanhood as an inhibiting factor in adolescent communication. Voprosy Psikhologii, 3, 29-40

Sgonnik, L.V. (2018). Reasons for social abandonment and their overcoming. Childhood protection: problems, searches, solutions. The collection of materials of the All-Russian scientific-practical conference dedicated to the Decade of childhood in Russia, 1, 587594.

The forms of statistical monitoring 103-RIC. (2019). URL: https://minobrnauki.rf (accessed 03.08.2019).

Vasilieva, E.Yu., \& Frolova, E.V. (2019). The Provision of Housing for Children-orphans and Children Left Without Parental Care: Key Issues and Regional Practices. Social Policy and Sociology, 3(132), 101-110.

Volkova, O.A., \& Besschetnova, O.V. (2013). Child abuse in Russia as a cause of social Orphanhood. World Applied Sciences Journal, 26(12), 1588-1594. 